\title{
ANALISIS PENGARUH MODERATING INVESTMENT OPPORTUNITY SET DENGAN KEBIJAKAN DIVIDEND SERTA MODERATING INVESTMENT OPPORTUNITY SET DENGAN ARUS KAS BEBAS TERHADAP TINGKAT LEVERAGE PERUSAHAAN MAKANAN DAN MINUMAN YANG TERDAFTAR DI BEI PERIODE 2003-2007
}

\author{
Masruroh; Tinjung Desy Nursanti; Lisa \\ Jurusan Manajemen, Fakultas Ekonomi dan Komunikasi, Binus University \\ Jl. KH. Syahdan No. 9, Palmerah, Jakarta Barat 11480.
}

\begin{abstract}
This research aims to examine whether there is any influence of investment opportunity set (IOS) on the affiliation between dividend policy and free cash flow to leverage enterprise-level. By using 42 samples of food and beverage companies listed on Indonesia Stock Exchange from 2003 to 2007, it is concluded that the dividend policy does not affect the company's leverage. However, the dividend policy together with investment opportunity set affect the level of corporate leverage. Free cash flow affects the level of corporate leverage. In the meantime, free cash flow to the investment opportunity set (IOS) also influences the level of corporate leverage, the dividend policy and free cash flow effect on the level of corporate leverage. Meanwhile, the dividend policy, free cash flow, investment opportunity set simultaneously affect the level of corporate leverage.
\end{abstract}

Keywords: leverage, investment opportunity set, dividend policy, free cash flow

\begin{abstract}
ABSTRAK
Penelitian ini bertujuan untuk menguji apakah ada pengaruh set kesempatan investasi (IOS) berhubungan dengan kebijakan dividen dan arus kas bebas untuk meningkatkan tingkat perusahaan. Dengan menggunakan 42 sampel perusahaan makanan dan minuman yang terdaftar di Bursa Efek Indonesia selama 2003-2007, dapat disimpulkan bahwa kebijakan dividen tidak mempengaruhi leverage perusahaan. Namun, kebijakan dividen bersama dengan set kesempatan investasi mempengaruhi tingkat leverage perusahaan. Arus kas bebas mempengaruhi tingkat leverage perusahaan. Sementara itu, arus kas bebas untuk set kesempatan investasi (IOS) juga mempengaruhi tingkat leverage perusahaan, kebijakan dividen dan arus kas berpengaruh pada tingkat leverage perusahaan. Sementara itu, kebijakan dividen, arus kas bebas, peluang investasi ditetapkan secara bersamaan mempengaruhi tingkat leverage perusahaan.
\end{abstract}

Kata kunci: leverage, set kesempatan investasi, kebijakan dividen, arus kas bebas 


\section{PENDAHULUAN}

Perusahaan dituntut untuk lebih berhati-hati lagi dalam menggunakan dana yang tersedia agar dapat bertahan dalam keadaan ekomoni yang terus menerus bergejolak. Menyikapi hal tersebut, perusahaan berupaya menggunakan kelebihan dana yang dimiliki untuk diinvestasikan pada projek yang prospektif. Pendanaan tersebut dapat diperoleh baik secara eksternal maupun internal. Pendanaan internal berasal dari dalam perusahaan itu sendiri yang disetor ataupun laba ditahan yang tidak dibagikan sebagai dividen kepada para pemegang saham, sedangkan pendanaan eksternal berasal dari hutang yang diperoleh dari pihak kreditor.

Manager perusahaan sebagai agen cenderung berperilaku oportunis demi kepentingannya sendiri, yang sering tidak sejalan dengan kepentingan principal. Untuk membatasi tindakan manajer perusahaan yang oportunis, shareholder memerlukan upaya pengawasan (monitoring). Tindakan pengawasan shareholder ini menimbulkan biaya keagenan (agency cost), yang terjadi karena adanya perbedaan kepentingan antara kedua belah pihak, di mana pemegang saham menginginkan sisa dana tersebut dibagikan untuk meningkatkan kesejahteraannya, sedangkan manajer menginginkan dana digunakan untuk investasi pada proyek-proyek yang menguntungkan karena pada masa mendatang akan menambah insentif bagi manajer.

Untuk menyelesaikan masalah keagenan ini, pemegang saham perlu mekanisme minimisasi biaya keagenan melalui kebijakan utang atau leverage. Berkaitan dengan fungsi sebagai mekanisme monitoring ini, dapat diindikasikan bahwa ada dua faktor yang diduga dapat memengaruhi tingkat utang perusahaan, yaitu dividen dan arus kas bebas. Dividen memiliki pengaruh terhadap leverage perusahaan, dengan hubungan yang positif, karena dividen dapat digunakan oleh shareholder untuk memaksa perusahaan mencari tambahan dana ke luar perusahaan. Peningkatan pembayaran dividen dapat merubah struktur modal perusahaan, karena mengurangi kas perusahaan dan memaksa manajemen mencari tambahan dana ke luar untuk merealisasikan rencana investasi atau untuk menjaga struktur modal tetap optimal.

Tingkat leverage juga dipengaruhi oleh tingginya free cash flow yang dimiliki perusahaan. Free cash flow yang terlalu besar akan mendorong manajer untuk memperlakukannya secara tidak efisien. Salah satu mekanisme untuk mengurangi tindakan inefisiensi manajer terhadap arus kas bebas adalah dengan kebijakan utang. Mekanisme dalam hal pengurangan masalah keagenan dapat dilakukan dengan menggunakan free cash flow untuk membayar dividen sehingga manajemen dipaksa mencari pendanaan dengan hutang untuk membiayai investasinya. investment opportunity set (IOS) digunakan sebagai variable moderating yang dapat memperkuat atau memperlemah hubungan kebijakan dividen dan arus kas bebas terhadap tingkat leverage perusahaan.

Penelitian ini merupakan replikasi dari penelitian Karsana dan Supriyadi (2005) dalam Analisa Moderasi Set Kesempatan Investasi Terhadap Hubungan Antara kebijakan dividen dan arus kas bebas Dengan Tingkat leverage Perusahaan, di mana sebelumnya digunakan data dari 83 perusahaan yang bukan keuangan atau observasi 332 pada tahun 1999 sampai dengan 2002. Perbedaan dari penelitian sebelumnya terletak pada tahun dasar yang berbeda, yaitu data perusahaan tahun 2003-2007, dengan objek penelitian perusahaan makanan dan minuman yang terdaftar di BEI.

\section{Rumusan Masalah}

(1) Apakah kebijakan dividen berpengaruh terhadap tingkat leverage perusahaan?

(2) Apakah kebijakan dividen dengan investment opportunity set (IOS) berpengaruh terhadap tingkat leverage perusahaan?

(3) Apakah arus kas bebas berpengaruh terhadap tingkat leverage perusahaan?

(4) Apakah arus kas bebas dengan investment opportunity set (IOS) berpengaruh terhadap tingkat leverage perusahaan? 
(5) Apakah kebijakan dividen dan arus kas bebas berpengaruh terhadap leverage perusahaan?

(6) Apakah kebijakan dividen, arus kas bebas, investment opportunity set (IOS) berpengaruh terhadap leverage perusahaan?

\section{Tujuan Penelitian}

Beberapa tujuan dari penelitian ini adalah: (1) melihat pengaruh dari kebijakan dividen itu sendiri dengan dimasukannya variable moderating, yaitu investment opportunity set (IOS) terhadap tingkat leverage perusahaan; (2) melihat pengaruh dari kebijakan dividen dengan dimasukannya variable moderating investment opportunity set (IOS) terhadap tingkat leverage perusahaan, akankah memperkuat atau memperlemah hubungan antara kebijakan dividen terhadap tingkat leverage perusahaan; (3) melihat pengaruh dari arus kas bebas itu sendiri tanpa dimasukkannya variable moderating, yaitu investment opportunity set (IOS) terhadap tingkat leverage perusahaan; (4) melihat pengaruh dari arus kas bebas dengan dimasukannya variable moderating investment opportunity set (IOS) terhadap tingkat leverage perusahaan, akankah memperkuat atau memperlemah hubungan antara arus kas bebas terhadap tingkat leverage perusahaan; (5) melihat pengaruh dari kebijakan dividen dan arus kas bebas secara bersama-sama tanpa dimasukannya oleh variable moderating, yaitu investment opportunity set (IOS) terhadap tingkat leverage perusahaan; (6) melihat pengaruh dari kebijakan dividen dan arus kas bebas secara bersama-sama dengan dimasukkannya variable moderating investment opportunity set (IOS) terhadap tingkat leverage perusahaan, akankah memperkuat atau memperlemah hubungan antara kebijakan dividen dan arus kas bebas terhadap tingkat leverage perusahaan.

\section{Landasan Teori}

\section{Investment Opportunity Set (IOS)}

Myres (1997) menyatakan bahwa investment opportunity set (IOS) is the extent to which firm value depends on future discretionary expenditures by the firm, yang diterjemahkan 'set kesempatan investasi adalah sejauh mana nilai perusahaan bergantung pada pengeluaran diskresioner masa depan'. Sedangkan Bodie, Kane, and Marcus (2008, p.158) menyatakan bahwa investment opportunity set (IOS) mengGambarkan pertumbuhan di masa depan. IOS adalah tersedianya alternatif investasi di masa yang akan datang bagi perusahaan (Hartono, 1999). IOS merupakan nilai sebagai pilihan-pilihan dari perusahaan untuk membuat investasi di masa yang akan datang (Myres, 1997). Hal ini didukung juga oleh Kallapur dan Trombley (1999) yang menyatakan bahwa IOS tidak dapat di observasi pihak luar perusahaan. Menurut Gaver dan Gaver (1993), investment opportunity set (IOS) merupakan nilai perusahaan yang besarnya tergantung pada pengeluaran-pengeluaran yang ditetapkan manajemen dana yang akan datang.

Investment opportunity set mempunyai beberapa proksi yang dapat di kelompokkan menjadi empat kelompok, yaitu: (1) Proksi berbasis harga (price-based proxies for IOS), di mana prospek pertumbuhan perusahaan sebagian dinyatakan dalam harga pasar, dan akan berbentuk rasio antara ukuran aktiva yang dimiliki dengan nilai pasar perusahaan. Perusahaan yang tumbuh akan memiliki nilai pasar lebih tinggi dibandingkan dengan aktiva yang dimiliki; (2) Proksi berbasis investment (investment-based proxies for IOS), yaitu kegiatan investasi yang benar berhubungan positif dengan nilai IOS. Perusahaan dengan IOS tinggi akan memiliki tingkat investasi yang tinggi pula dalam bentuk aktiva yang diinvestasikan untuk waktu yang lama di sebuah perusahaan; (3) Proksi berbasis varian (varian-based proxies for IOS) - sebuah opsi akan menjadi lebih bernilai jika menggunakan variabilitas ukuran yang memperkirakan besarnya opsi yang tumbuh seperti variabilitas return yang mendasari peningkatan aktiva; (4) Proksi gabungan (composite measures), digunakan untuk mengurangi kesalahan pengukuran pemilihan variabel tunggal untuk proksi investment opportunity set (IOS). Banyak studi menggunakan proksi investment opportunity set (IOS) secara individu dan berusaha untuk mengevaluasi sensitivitas hasil dalam memilih proksi IOS (Gaver dan Gaver, 1993). 


\section{Kebijakan Dividen}

Menurut Weston \& Copeland (1992, p.657) "Dividend policy determines the division of earnings between paymen to shareholder and reinvestment in the firm." Artinya 'Kebijakan dividen adalah penentuan pembagian pendapatan antara pembagian dividen untuk pemegang saham dan untuk reinvestasi dalam perusahaan.' Sedangkan Brigham (2005, p.613) menyatakan 'Dividend policy involves the decisions to pay out earning to retain than for reinvestment in the firm." Artinya 'Kebijakan dividen melibatkan keputusan untuk menbayar dividen atau menahan dividen tersebut untuk reinvestasi dalam perusahaan.' Adapun beberapa faktor penting yang mempengaruhi kebijakan dividen adalah kesempatan investasi yang tersedia, ketersediaan dan biaya modal alternatif, dan preferensi pemegang saham untuk menerima pendapatan saat ini atau masa depan.

\section{Arus Kas Bebas}

Arus kas bebas merupakan laporan tentang arus kas masuk dan keluar yang utama dari sebuah perusahaan selama suatu periode tertentu. Tujuannya untuk mengevaluasi kegiatan operasional perusahaan pada periode lalu, dan untuk merancanakan kegiatan pendanaan dan investasi di periode mendatang.

\section{Leverage}

Salah satu keputusan penting dalam menajemen adalah bagaimana sebuah perusahaan memperoleh modal guna mendanai kegiatan operasionalnya dan memenuhi kebutuhan investasinya dan cara untuk memenuhi dana, apakah dengan hutang (leverage) atau dengan menerbitkan saham atau obligasi. Semakin tinggi leverage semakin besar dispersi return, dengan kata lain semakin besar leverage mengakibatkan semakin bergejolaknya return atas modal sendiri. Jadi pengertian hutang adalah penggunaan dana yang berasal dari pinjaman perusahaan dalam rangka pengembangan perusahaan (assets dan expansi) yang menimbulkan beban bunga yang dibayarkan per periode.

\section{Penelitian Terdahulu}

\section{Pengaruh Investment Opportunity Set (IOS) dengan Kebijakan Dividen terhadap Tingkat Leverage Perusahaan}

Perusahaan dengan tingkat pertumbuhan yang rendah cenderung membayar dividen lebih besar, agar dapat mengalihkan sumber dana perusahaan biar tidak ditanamkan dalam proyek dengan Net Present Value negatif. Kebijakan dividen akan mempengaruhi perusahaan untuk melakukan investasi, tetapi apabila perusahaan tidak mempunyai cukup dana untuk investasi, maka perusahaan akan mencari dana eksternal dari sumber lain dengan tingkat risiko yang kecil, yaitu utang, sehingga dapat diduga adanya hubungan positif antara kebijakan dividen dengan utang perusahaan atau leverage.

Baskin (1989) dan Adedeji (1998) menemukan bahwa dividen mempunyai pengaruh positif terhadap financial leverage. Sebaliknya Allen (1993) menemukan bahwa dividen mempunyai pengaruh negatif terhadap financial leverage. Hartono (1999) menemukan bahwa kebijakan dividen mempengaruhi leverage perusahaan secara positif, tetapi tidak mempengaruhi kebijakan dividen.

Menurut Myres (1997) perusahaan dengan investment opportunity set (IOS) tinggi menunjukkan bahwa nilai perusahaan lebih banyak ditentukan oleh intangible asset dari pada asset riil-nya. Perusahaan tipe ini biasanya akan memiliki keterbatasan untuk mendapatkan utang, karena mereka kurang memiliki asset riil yang dapat digunakan sebagai jaminan utang. Selain itu, investment opportunity set (IOS) tinggi mencerminkan tinggi risiko yang harus ditanggung lender sehingga menyebabkan cost of debt bagi perusahaan dan kemampuan perusahaan untuk akses ke lender, 
sehingga dapat disimpulkan bahwa investment opportunity set (IOS) dapat berfungsi sebagai variable moderasi yang mempengaruhi kuatnya hubungan antara tingkat dividen tunai dengan tingkat leverage perusahaan. Penelitian Gaver \& Gaver (1993) mengindikasikan hubungan positif antara IOS dengan kebijakan pendanaan dan dividen.

\section{Pengaruh Investment Opportunity Set (IOS) dengan arus kas bebas terhadap Tingkat Leverage Perusahaan}

Jensen (1995) menyatakan bahwa utang dapat mengurangi keleluasaan manajemen menggunakan arus kas bebas untuk kegiatan yang bersifat non maximizing value. Semakin besar arus kas perusahaan, semakin besar kemungkinan terjadi pemborosan yang dilakukan manajer, sehingga diperlukan tingkat utang yang tinggi untuk mengontrol tindakan manajer yang cenderung non maximizing value. Perusahaan dengan investment opportunity set (IOS) rendah biasanya memiliki nilai free cash flow tinggi, karena perusahaan tersebut tidak lagi mempunyai potensi untuk ekspansi. Dapat disimpulkan, perusahaan dengan arus kas bebas yang tinggi akan diikuti nilai IOS yang rendah karena IOS mencerminkan peluang tumbuh suatu perusahaan.

Friend dan Lang (1998) menyatakan bahwa penggunaan utang yang berlebih akan mengurangi cash flow karena sebagian besar cash flow untuk membayar utang, sehingga tidak ada cash flow dalam perusahaan yang dapat dimanfaatkan oleh manajer untuk melakukan tindakan perquisites yang merugikan shareholder, dengan sendirinya konflik keagenan tidak akan terjadi. Jensen (1995) menyatakan bahwa perusahaan dengan free cash flow besar cenderung mempunyai level hutang yang lebih tinggi khususnya saat perusahaan mempunyai kesempatan investasi yang rendah. Perusahaan dengan free cash flow besar dengan tingkat leverage tinggi akan menurunkan agency cost free cash flow, demikian pula sebaliknya. Penelitian Jaggi dan Gul (1999) menguji hipotesis Jensen (1995) tentang control hypothesis dan hasilnya menunjukkan ada hubungan positif antara utang dengan arus kas bebas untuk perusahaan dengan tingkat kesempatan investasi rendah.

\section{Model Penelitian}

Dependent variable dalam penelitian adalah tingkat leverage perusahaan $(\mathrm{Y})$. Independent variable-nya adalah kebijakan dividen $\left(\mathrm{X}_{1}\right)$ dan arus kas bebas $\left(\mathrm{X}_{2}\right)$. Semantara moderating variable yang digunakan adalah investment opportunity set (IOS) $\left(\mathrm{X}_{3}\right)$. Untuk lebih jelasnya berikut bagan model penelitian yang digunakan (Gambar 1).

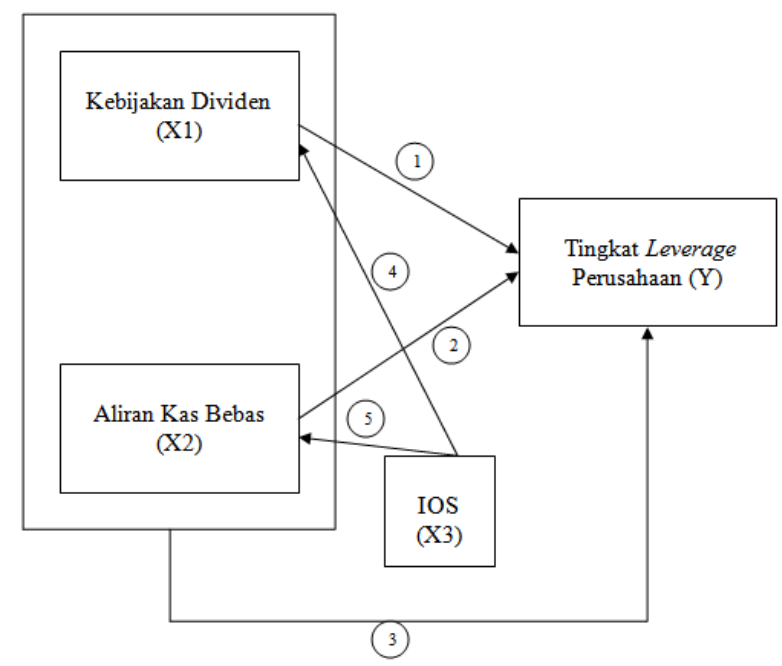

Gambar 1. Model penelitian. 


\section{Perumusan Hipotesis}

Dalam penelitian ini terdapat enam hipotesis yaitu:

Ho$_{1}$ : Kebijakan dividen tidak berpengaruh terhadap tingkat leverage perusahaan

$\mathbf{H a}_{1}$ : Kebijakan dividen mempengaruhi tingkat leverage perusahaan.

$\mathbf{H o}_{2}$ : Kebijakan dividen dengan investment opportunity set (IOS) tidak berpengaruh terhadap tingkat leverage perusahaan

$\mathbf{H a}_{2}$ : Kebijakan dividen dengan investment opportunity set (IOS) mempengaruhi tingkat leverage perusahaan

$\mathbf{H o}_{3}$ : Aliran kas bebas tidak berpengaruh terhadap tingkat leverage perusahaan

$\mathbf{H a}_{3}$ : Arus kas bebas berpengaruh terhadap tingkat leverage perusahaan

$\mathbf{H o}_{4}$ : Arus kas bebas dengan investment opportunity set (IOS) tidak berpengaruh terhadap tingkat Leverage perusahaan.

Ha $_{4}$ : Arus kas bebas dengan investment opportunity set (IOS) berpengaruh terhadap tingkat leverage perusahaan.

Ho $_{5}$ : Kebijakan dividen dan arus kas bebas tidak berpengaruh terhadap tingkat leverage perusahaan.

$\mathbf{H a}_{5}$ : Kebijakan dividen dan arus kas bebas berpengaruh terhadap tingkat leverage perusahaan.

Ho $_{6}$ : Kebijakan dividen, arus kas bebas, investment opportunity set (IOS) tidak berpengaruh terhadap tingkat leverage perusahaan.

Ha $_{6}$ : Kebijakan dividen, arus kas bebas, investment opportunity set (IOS) berpengaruh terhadap tingkat leverage perusahaan.

\section{METODE PENELITIAN}

Penelitian ini merupakan penelitian korelasional dengan tipe kausalitas, yang bertujuan untuk mengetahui pengaruh antara variabel dependent (tingkat leverage) dan independent variable (kebijakan dividend dan free cash flow) serta IOS sebagai variable moderating. Objek penelitian ini adalah perusahaan manufaktur yang bergerak dalam bidang makanan dan minuman yang mempublikasikan laporan keuangannya di BEI (Bursa Efek Indonesia) secara lengkap, dengan horizon waktu selama periode 2003-2007. Metode sampling yang digunakan adalah purposive sampling.

\section{Definisi Operasional Variabel dan Pengukurannya}

Proksi leverage dalam penelitian ini adalah sebagai berikut:

${ }_{-}$DER $=\frac{\text { TotalDebt }}{\text { Equity }}$

Independent variable pertama yaitu dividend, diukur dengan dividend payout ratio (DPR) yaitu persentase laba yang dibayarkan dalam bentuk dividen, yaitu rasio antara dividend per share (DPS) dengan earnings per share (EPS), dengan formula berikut:

DPR $=\frac{\text { DPS }}{\text { EPS }}$

Independent variable kedua yaitu Free cash flow, diperoleh dengan mengurangkan arus kas operasi dengan pengeluaran modal bersih dan modal kerja bersih. Formula matematisnya adalah sebagai berikut: 


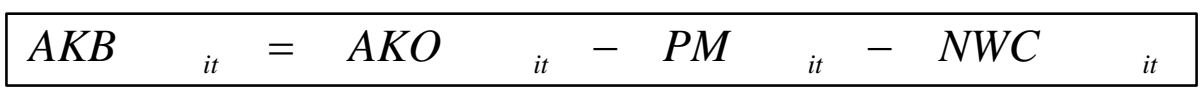

Keterangan:

AKO = arus kas operasional, yaitu kas yang berasal dari kegiatan utama perusahaan dan aktivitas lainnya, selain dari kegiatan investasi dan kegiatan pendanaan.

$\mathrm{PM}=$ pengeluaran modal yang diukur dengan cara mengurangi nilai aktiva tetap akhir dengan nilai aktiva tetap awal.

NWC = Net Working Capital, yaitu selisih antara jumlah aktiva lancar dengan utang lancar pada tahun yang sama.

Moderating variable dalam penelitian ini adalah investment opportunity set (IOS) yaitu variabel yang tidak dapat diobservasi, sehingga diperlukan proksi untuk keperluan analisis empiris. Penelitian ini menggunakan proksi price based, market-to-book value of equity (MVEBVE), dengan rumus matematis berikut:

\begin{tabular}{|c|c|c|c|c|c|c|}
\hline RVF & Lembar & Saham & Beredar & $X \quad H$ arg & $a \quad$ Saham & Penutupan \\
\hline EDVE & & & Tota & Ekuitas & & \\
\hline
\end{tabular}

\section{Teknik Pengumpulan Data}

Populasi penelitian ini adalah perusahaan yang terdaftar di BEI (Bursa Efek Indonesia). Ada beberapa kriteria yang ditetapkan dalam pemilihan sample, yaitu: (1) Perusahaan terdaftar di BEI dan mempublikasikan laporan keuangan lengkap secaraa konsisten dari tahun 2003 sampai dengan 2007; (2) Bukan perusahaan perbankan, keuangan dan asuransi karena perusahaan jenis keuangan dan perbankan mempunyai kebijakan pendanaan yang berbeda dengan perusahaan dalam jenis industri yang lain; (3) Pernah membagi dividen tunai dalam periode pengamatan; (4) Memiliki data lengkap dan tidak memiliki saldo ekuitas negatif karena menyebabkan rasio keuangan yang dihasilkan menjadi tidak bermakna.

\section{Metode Analisis Data}

Metode analisis data dalam penelitian ini menggunakan SPSS versi 11.5. Pertama-tama dilakukan uji normalitas data yang bertujuan untuk mengetahui apakah dalam model regresi, variable pengganggu atau residual memiliki distribusi normal. Dilanjutkan uji asumsi klasik untuk mengetahui masalah regresi yang ada, meliputi uji Multikolinieritas, Autokolerasi dan Uji Heteroskedastisitas. Berikutnya melakukan Uji Hipotesis dengan menghitung koefisien determinasi $\left(\mathrm{R}^{2}\right)$ untuk mengukur seberapa jauh kemampuan model dalam menerangkan variabel-variabel dependent, Uji $F$ untuk mengetahui apakah independent variable (secara bersama-sama) berpengaruh secara signifikan atau tidak terhadap dependent variable. Bila signifikan berpengaruh berarti model yang diuji adalah model yang baik dipakai dalam penyederhanaan dunia nyata. Uji T untuk mengetahui pengaruh independent variable secara individu terhadap dependent variable.

\section{HASIL DAN PEMBAHASAN}

\section{Gambaran Umum Sample (Objek Penelitian)}

Penelitian ini menggunakan sample sebanyak sembilan perusahaan makananan dan minuman yang terdaftar di BEI, dan data observasi sebanyak 45 data selama periode pengamatan dari tahun 2003 sampai dengan tahun 2007. Adapun perusahaan-perusahaan makanan dan minuman yang menjadi objek dalam penelitian ini, dapat dilihat pada Table 1 berikut: 
Tabel 1 Nama-nama Perusahaan Makanan dan Minuman

\begin{tabular}{ccl}
\hline No & Perusahaan & \multicolumn{1}{c}{ Keterangan } \\
\hline 1 & AQUA & PT. Aqua Golden Mississippi Tbk. \\
2 & CEKA & PT. Cahaya Kalbar Tbk. \\
3 & DLTA & PT. Delta Djakarta Tbk. \\
4 & FAST & PT. Fast Food Indonesia Tbk. \\
5 & INDF & PT. Indofood Sukses Makmur Tbk. \\
6 & MLBI & PT. Multi Bintang Indonesia Tbk. \\
7 & MYOR & PT. Mayora Indah Tbk. \\
8 & TLBA & PT. Tunas Baru Lampung Tbk. \\
9 & ULTJ & PT. Ultrajaya Milk Tbk. \\
\hline
\end{tabular}

\section{Statistik Deskriptif}

Dari pengujian sample yang berjumlah sembilan dengan jumlah observasi sebanyak 45, dapat dilihat nilai rata-rata atau mean masing-masing variabel, yaitu: DER (leverage) sebesar 1.0382, DPR (dividen) sebesar 23.5673, AKB (arus kas bebas) sebesar -410592, dan yang terakhir IOS memiliki nilai rata-rata sebesar 1.915811. Hasil analisis statistik deskriptif, menunjukkan nilai maksimum dan minimum dalam variabel-variabel penelitian ini. Variabel dengan nilai paling minimum dari data yang terdapat pada Tabel 4.2 adalah DPR (dividen) yaitu 0.00 pada perusahaan ULTJ, sedangkan variabel dengan nilai paling maksimum dari pengujian yang dilakukan adalah AKB sebesar 266168.00 pada perusahaan MLBI pada periode 2007. Hasil pengujian atas nilai standar deviasi yang diperoleh masing-masing variabel adalah: DER (leverage) sebesar 0.70284, DPR (dividen) sebesar 51.57553, AKB (arus kas bebas) sebesar 623575.5, dan IOS sebesar 1.3444771 (Tabel 2).

Tabel 2 Analisis Statistik Deskriptif

\begin{tabular}{|c|c|c|c|c|c|}
\hline & & DER & DPR & $\mathrm{AKB}$ & IOS \\
\hline \multirow[t]{2}{*}{$\mathrm{N}$} & Valid & 45 & 45 & 45 & 45 \\
\hline & Missing & 9 & 9 & 9 & 9 \\
\hline \multicolumn{2}{|c|}{ Mean } & 1.0382 & 23.5673 & -410592 & 1.915811 \\
\hline \multicolumn{2}{|c|}{ Std. Deviation } & .70284 & 51.57553 & 623575.5 & 1.3444771 \\
\hline \multicolumn{2}{|c|}{ Minimum } & .24 & .00 & -2686148 & .2844 \\
\hline \multicolumn{2}{|c|}{ Maximum } & 2.62 & 319.00 & 266168.00 & 5.8416 \\
\hline
\end{tabular}

\section{Uji Kualitas Data}

Uji kualitas data digunakan untuk menguji kenormalan data-data yang terdapat dalam penelitian ini. Dalam penelitian ini terdapat 3 jenis uji normalitas.

\section{Uji Normalitas Data}

Uji histogram merupakan salah satu dari tiga cara yang dilakukan untuk menguji kenormalan data di dalam penelitian ini. Dari Gambar 4.1, terlihat bahwa grafik histogram memberikan pola distribusi dengan kurva sedikit menceng ke kiri dan hal ini menyalahi asumsi normalitas, sehingga data ini tidak berdistribusi normal, dengan standar deviasi .097, mean 0.00, dan jumlah data sebanyak 45 (Gambar 2). 


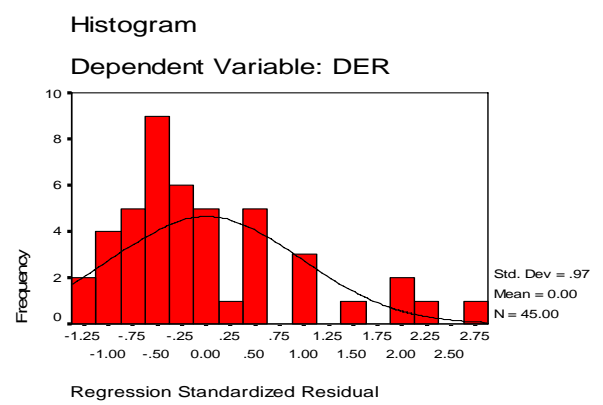

Gambar 2. Histogram uji normalitas data.

Uji normalitas kedua adalah P-Plot (Gambar 3) yang digunakan untuk melihat kenormalan suatu data dari titik-titik yang mengikuti garis diagonal. Dari Gambar 3 dapat dilihat bahwa grafik normal P-Plot dapat dilihat dari titik-titik yang menyebar di sekitar garis diagonal, tetapi tidak mengikuti garis diagonal. Dapat disimpulkan bahwa data yang diuji tidaklah normal.

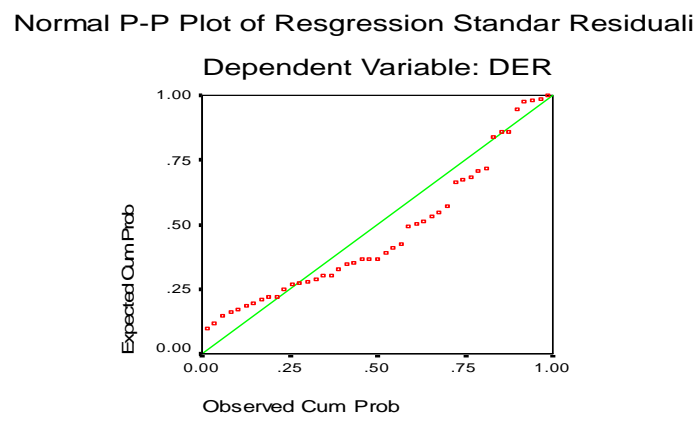

Gambar 3. P-Plot.

Uji normalitas yang ketiga dengan menggunakan uji One-Sample Kolmogorov-Smirnov dengan hasil berikut (Tabel 3).

Tabel 3 One-Sample Kolmogorov-Smirnov Test

\begin{tabular}{llrrrr}
\hline & & DER & DPR & AKB & \multicolumn{1}{c}{ IOS } \\
\hline $\mathrm{N}$ & & 45 & 45 & 45 & 45 \\
Normal Parameters(a,b) & Mean & 1.0382 & 23.5673 & -410592.4444 & 1.915811 \\
& Std. Deviation & .70284 & 51.57553 & 623575.45313 & 1.34444771 \\
\multirow{2}{*}{ Most Extreme Differences } & Absolute & .217 & .324 & .251 & .126 \\
& Positive & .217 & .315 & .163 & .126 \\
& Negative & -.128 & -.324 & -.251 & -.113 \\
Kolmogorov-Smirnov Z & & 1.454 & 2.172 & 1.684 & .844 \\
Asymp. Sig. (2-tailed) & & .029 & .000 & .007 & .474 \\
\hline
\end{tabular}

a Test distribution is Normal.

B Calculated from data.

Dari hasil uji normalitas One-Sample Kolmogorov-Smirnov Test, didapat hasil dari masingmasing variabel penelitian ini, yaitu: (1) Variabel dependent DER (leverage) mempunyai nilai Kolmogorov-Smirnov 1.454 dan nilai signifikan sebesar 0.029, sehingga dapat dikatakan variabel ini tidak berdistribusi normal karena nilai signifikan lebih kecil dari 5\% atau 0.05; (2) Independent variable pertama yaitu DPR (Dividen) mempunyai nilai Kolmigorov-Smirnov 2.172 dan nilai 
signifikan 0.000 (lebih kecil dari 5\% atau 0.05), maka variabel ini tidak berdistribusi normal; (3) Independent variable kedua adalah AKB (arus kas bebas) mempunyai nilai Kolmigorov-Smirnov 1.684 dan nilai signifikan 0.007 (kurang dari 5\% atau 0.05), sehingga variabel ini juga tidak berdistribusi normal; (4) Variable IOS (Investment Opportunity Set) mempunyai nilai KolmigorovSmirnov sebesar 0.844 dan nilai signifikannya sebesar 0.474 (lebih besar dari $5 \%$ atau 0.05 ) sehingga variabel ini dapat dikatakan berdistribusi normal.

\section{Uji Outlier}

Ketiga hasil pengujian normalitas di atas menunjukkan bahwa variabel-variabel dalam penelitian ini masih tidak berdistribusi normal, sehingga harus dibuat normal dengan menggunakan uji outlier, yang dilakukan dengan cara menambah data, menstransformasi data, atau mengurangi data yang bersifat ekstrim (outlier). Penelitian ini menggunakan pilihan ketiga yaitu menghilangkan data yang bersifat ekstrim, yang dapat dilakukan dengan tiga cara pula, yaitu: (1) menghilangkan data yang lebih kecil dari -3.00 dan lebih besar dari 3.00, (b) jika masih tidak normal, nilai data yang lebih kecil dari -2.56 dan lebih besar dari 2.56 harus dihilangkan, (c) menghilangkan data yang lebih kecil dari 1.96 dan lebih besar dari 1.96, dengan hasil sebagai berikut:

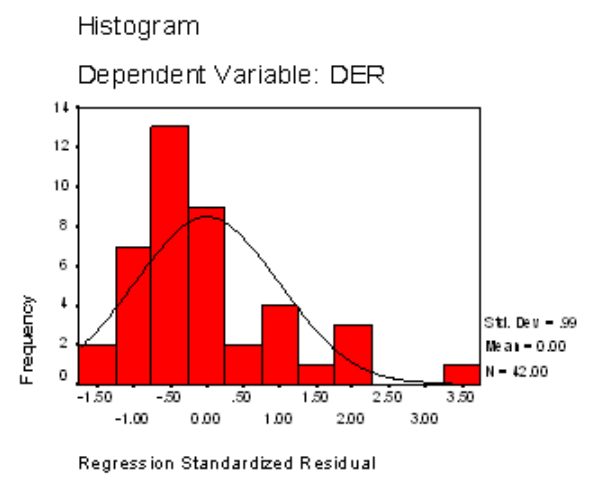

Gambar 4. Histogram uji outlier.

Dengan kurva normalitas masih belum berbentuk sempurna, kurva tidak membentuk lonceng yang sempurna, masih sedikit menceng ke kiri. Hal ini telah menyalahi asumsi normalitas, dan data juga masih dinyatakan belum berdistribusi normal. Untuk itu perlu juga dilakukan uji P-Plot (Gambar 5).



Gambar 5. P-Plot hasil uji outlier.

Dengan titik-titik yang terdapat di sekitar garis diagonal atau garis distribusi normalitas, masih belum mengikuti garis diagonal tesebut, sehingga uji normalitas P-Plot ini juga masih belum bisa dikatakan berdistribusi normal. 
Dari hasil pengujian normalitas histrogram dan P-Plot, dilakukan lagi uji normalitas OneSample Kolmogorov-Smirnov Test (Tabel 4), agar data dalam penelitian ini dapat berdistribusi normal. Hasil pengujian normalitas One-Sample Kolmogorov-Smirnov Test adalah: (1) Dependent variable DER (leverage) mempunyai nilai Kolmogorov-Smirnov 1.355 dan nilai signifikan 0.051, jadi dapat dikatakan bahwa variabel ini berdistribusi normal karena nilai signifikannya lebih besar dari 5\% atau 0.05; (2) Independent variable pertama yaitu DPR (Dividen) mempunyai nilai KolmogorovSmirnov 1.271 dan nilai signifikan 0.75 , atau lebih besar dari $5 \%$ atau 0.05 , maka dapat dikatakan bahwa variabel ini berdistribusi normal; (3) Independent variable kedua adalah AKB (arus kas bebas) mempunyai nilai Kolmogorov-Smirnov 1.176 dan nilai signifikan sebesar 0.126, maka dapat disimpulkan bahwa variabel ini juga tidaklah berdistribusi normal, karena nilai signifikannya lebih besar dari 5\% atau 0.05; (4) Sedangkan variabel IOS (Investment Opportunity Set) mempunyai nilai Kolmogorov-Smirnov .837 dan nilai signifikan 0.485, maka variabel ini dapat dikatakan normal karena nilai signifikannya lebih besar dari $5 \%$ atau 0.05 .

Tabel 4 One-Sample Kolmogorov-Smirnov Test Setelah Outlier

\begin{tabular}{|c|c|c|c|c|c|c|}
\hline & & & Zscore(DER) & Zscore(DPR) & Zscore(AKB) & Zscore(IOS) \\
\hline \multicolumn{3}{|l|}{$\mathrm{N}$} & 42 & 42 & 42 & 42 \\
\hline \multirow{2}{*}{\multicolumn{2}{|c|}{$\begin{array}{l}\text { Normal } \\
\text { Parameters(a,b) }\end{array}$}} & Mean & -.0889359 & -.1348499 & .1485485 & -.0064294 \\
\hline & & Std. Deviation & .90106086 & .49538444 & .70460783 & 1.01394849 \\
\hline \multirow{3}{*}{\multicolumn{2}{|c|}{$\begin{array}{ll}\text { Most } & \text { Extreme } \\
\text { Differences } & \end{array}$}} & Absolute & .209 & .258 & .181 & .129 \\
\hline & & Positive & .209 & .257 & .129 & .129 \\
\hline & & Negative & -.123 & -.258 & -.181 & -.117 \\
\hline \multicolumn{3}{|c|}{ Kolmogorov-Smirnov Z } & 1.355 & 1.271 & 1.176 & .837 \\
\hline \multicolumn{3}{|c|}{ Asymp. Sig. (2-tailed) } & .051 & .075 & .126 & .485 \\
\hline
\end{tabular}

a Test distribution is Normal.

b Calculated from data.

\section{Uji Asumsi Klasik}

Pengujian asumsi klasik dilakukan untuk melihat apakah di dalam model regresi yang digunakan terjadi korelasi. Penelitian ini menggunakan tiga jenis uji asumsi klasik.

Pertama adalah uji multikolinieritas. Model regresi dapat memiliki kolerasi atau terjadi multikolinieritas jika nilai VIF-nya lebih dari 10, atau nilai tolerance-nya mendekati nilai 0.1. Hasil yang didapat dari pengujian tersebut dapat dilihat nilai Tolerance dan VIF dari masing-masing variabel, yaitu DPR (Dividen) dengan nilai Tolerance 0.417 dan VIF 2.395, AKB (arus kas bebas) dengan nilai Tolerance 0.937, dan nilai VIF 1.067, dan yang terakhir IOS (Investment Opportunity Set) dengan nilai Tolerance 0.428 dan nilai VIF 2.336, maka dapat disimpulkan dari ketiga variabel tersebut nilai Tolerance-nya tidak ada yang mendekati nilai 0.1, dan nilai VIF-nya pun tidak ada yang lebih dari nilai 10. Oleh karena itu, pada model regresi penelitian ini tidak terjadi multikolinieritas.

Pengujian kedua adalah uji heteroskedastisitas. Dari Gambar scatterplot terlihat bahwa data menyebar ke atas dan ke bawah, sehingga disimpulkan bahwa pada model regresi ini terjadi heterokedastisitas. Uji ketiga adalah autokolerasi Durbin Watson dengan hasil pada Tabel 5 di bawah ini: 
Tabel 5 Autokorelasi Model Summary(b)

\begin{tabular}{|c|c|c|c|c|c|c|}
\hline Model & $\mathrm{R}$ & R Square & $\begin{array}{l}\text { Adjusted } \\
\text { Square } \\
\end{array}$ & $\mathrm{R}$ & $\begin{array}{l}\text { Std. Error of the } \\
\text { Estimate }\end{array}$ & Durbin-Watson \\
\hline 1 & $.653(\mathrm{a})$ & .426 & .381 & & .49827 & 2.534 \\
\hline
\end{tabular}

a Predictors: (Constant), IOS, AKB, DPR

b Dependentt Variable: DER

Untuk mengetahui apakah dalam suatu model penelitian atau model regresi terjadi autokolerasi atau tidak, digunakan ketentuan sebagai berikut:

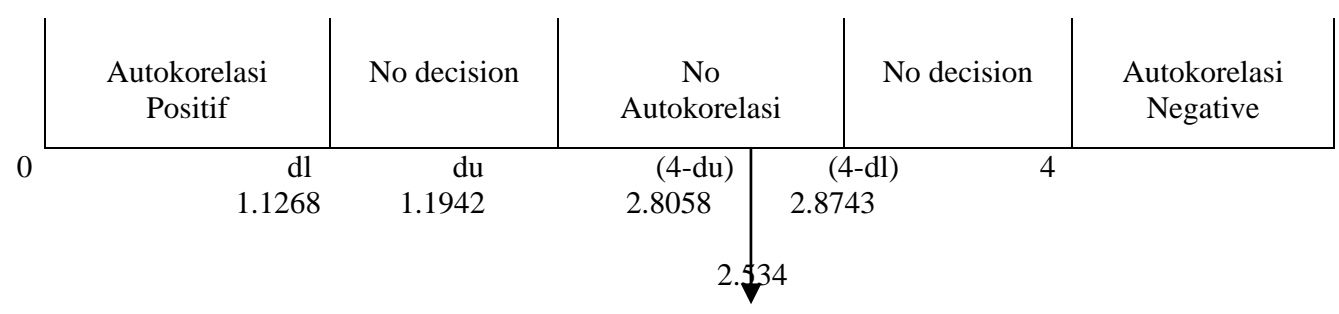

Nilai uji Durbin Watson pada Tabel 5 adalah 2.534, artinya lebih besar dari batas atas (du) sebesar 1.1942 dan lebih kecil dari nilai 4-1.1942 (4-du) sebesar 2.8058. Nilai 2.8058 berada pada area yang menunjukkan kriteria keputusan tidak terjadi autokorelasi, sehingga dapat disimpulkan bahwa model regresi ini tidak terdapat autokorelasi.

\section{Analisa Pengujian Koefisien Determinasi dan Pengujian Hipotesis $\mathrm{Ha}_{1}=$ Kebijakan Dividen berpengaruh terhadap tingkat Leverage perusahaan}

\section{Koefisien Determinasi}

Pada Tabel 6 di bawah ini dapat dilihat besarnya nilai koefisien kolerasi (R) adalah 0.095 atau 9.5\%. Hal ini menunjukkan bahwa pengaruh antara kebijakan dividen dengan tingkat leverage perusahaan rendah atau hampir tidak ada hubungan. Nilai $\mathrm{R}^{2}$ pada Tabel 4.7 sebesar 0.009 atau $0.9 \%$ yang berarti variasi variabel dependent tingkat leverage perusahaan yang bisa dijelaskan oleh independent variable kebijakan dividen adalah sebesar 0.09\%, sedangkan sisanya sebesar $99.1 \%$ dijelaskan oleh variabel lain yang tidak terdapat dalam model regresi tersebut.

Tabel 6 Tabel Uji R dan $R^{2}$ - Model Summary

\begin{tabular}{llrrr}
\hline Model & $\mathrm{R}$ & R Square & $\begin{array}{c}\text { Adjusted R } \\
\text { Square }\end{array}$ & $\begin{array}{l}\text { Std. Error of } \\
\text { the Estimate }\end{array}$ \\
\hline 1 & $.095(\mathrm{a})$ & .009 & -.014 & .70774 \\
\hline
\end{tabular}

a Predictors: (Constant), DPR

\section{Pengujian Hipotesis}

$\mathrm{Ho}_{1} \quad$ : Kebijakan Dividen tidak berpengaruh terhadap tingkat leverage perusahaan.

$\mathrm{Ha}_{1} \quad$ : Kebijakan Dividen berpengaruh terhadap tingkat leverage perusahaan. 
Dari Tabel 7 di bawah ini didapat nilai sig dari variable dependent DPR (Dividen) ini sebesar 0.534 dan lebih besar dari $\alpha=0.05$, artinya $\mathrm{Ho}_{1}$ diterima dan $\mathrm{Ha}_{1}$ ditolak (Lihat Kurva Penerimaan atau Penolakan Ha dan Ho (Gambar 6)), yaitu kebijakan dividen tidak berpengaruh terhadap tingkat leverage perusahaan. Dari Gambar 6 didapat nilai $t$ Tabel yang diperoleh sebesar 2.0211, sedangkan nilat $t$ hitung yang terdapat pada Tabel 4.8 sebesar 0.627 , hal ini menunjukkan bahwa nilai $t$ hitungnya lebih kecil dari nilai $t$ Tabel, sehingga Ho diterima dan Ha ditolak, dan didukung dengan nilai sig nya, sehingga dapat dibuat model regresi berikut:

$$
\mathrm{Y}=1.008+0.001 \mathrm{X} 1+\varepsilon 1
$$

Keterangan:

$\mathrm{Y}$ : tingkat leverage perusahaan

$\mathrm{X} 1$ : kebijakan dividen

Dapat disimpulkan bahwa independent variable kebijakan dividen memiliki koefisien regresi sebesar 0.001 artinya bila independent variable naik $1 \%$ maka variabel dependent tingkat leverage perusahaan akan naik $0.001 \%$.

Tabel 7 Tabel Uji T Statistik - Coefficients(a)

\begin{tabular}{|c|c|c|c|c|c|c|}
\hline \multirow[b]{2}{*}{ Model } & & \multicolumn{2}{|c|}{ Unstandardized Coefficients } & \multirow{2}{*}{$\begin{array}{c}\text { Standardized } \\
\text { Coefficients } \\
\text { Beta }\end{array}$} & \multirow[b]{2}{*}{$\mathrm{t}$} & \multirow[b]{2}{*}{ Sig. } \\
\hline & & B & Std. Error & & & \\
\hline \multirow[t]{2}{*}{1} & (Constant) & 1.008 & .116 & & 8.670 & .000 \\
\hline & DPR & .001 & .002 & .095 & .627 & .534 \\
\hline
\end{tabular}

a Dependentt Variable: DER



Gambar 6. Kurva Penerimaan atau Penolakan Ha dan Ho.

\section{$\mathrm{Ha}_{2}=$ Kebijakan dividen dengan Investment Opportunity Set berpengaruh terhadap tingkat Leverage perusahaan.}

\section{Koefisien Determinasi}

Pada Tabel 8 di bawah ini dapat dilihat besar nilai koefisien kolerasi (R) adalah 0.432 atau 43.2\% yang menunjukkan bahwa pengaruh antara kebijakan dividen dengan tingkat leverage perusahaan adalah sedang atau memiliki hubungan setelah dimasukkan variable moderatin investment opportunity set (IOS). Nilai adjusted $\mathrm{R}^{2}$ pada Tabel 8 sebesar 0.148 atau $14.8 \%$ yang berarti variasi variabel dependent tingkat leverage perusahaan yang bisa dijelaskan oleh independent variable kebijakan dividen bersama dengan variable moderating investment opportunity set (IOS) adalah $14.8 \%$, sedangkan sisanya sebesar $85.2 \%$ dijelaskan oleh variabel lainnya yang tidak terdapat di dalam model regresi tersebut. 
Tabel 8 Tabel Uji R dan $R^{2}$ - Model Summary

\begin{tabular}{llrrr}
\hline Model & $\mathrm{R}$ & R Square & $\begin{array}{c}\text { Adjusted R } \\
\text { Square }\end{array}$ & $\begin{array}{l}\text { Std. Error of } \\
\text { the Estimate }\end{array}$ \\
\hline 1 & $.432(\mathrm{a})$ & .187 & .148 & .64869 \\
\hline
\end{tabular}

a Predictors: (Constant), IOS, DPR

\section{Pengujian Hipotesis}

$\mathrm{Ho}_{2}$ : Kebijakan Dividen dengan investment opportunity set (IOS) tidak berpengaruh terhadap tingkat leverage perusahaan.

$\mathrm{Ha}_{2}$ : Kebijakan Dividen dengan investment opportunity set (IOS) berpengaruh terhadap tingkat leverage perusahaan.

Dari Tabel 9 di bawah ini, nilai sig dari variable dependent DPR (Dividen) dan Variable moderating (IOS) adalah 0.013 dan nilai ini lebih kecil dari pada $\alpha=0.05$, artinya $\mathrm{Ho}_{2}$ ditolak dan $\mathrm{Ha}_{2}$ diterima, yaitu kebijakan dividen dengan investment opportunity set (IOS) berpengaruh terhadap tingkat leverage perusahaan. Selain itu nilai $F$ Tabel yang diperoleh adalah sebesar 2.84. Sedangkan nilai $F$ hitung yang terdapat pada Tabel 9 adalah sebesar 4.826, dan hal ini menunjukkan bahwa nilai $t$ hitungnya lebih besar dari nilai $t$ tabel, di mana nilai $t$ hitung ini berada di daerah Ho ditolak, maka Ho ditolak dan Ha diterima, dan hal ini didukung pula dengan nilai sig nya.

Tabel 9 Tabel Uji F Statistik - ANOVA(b)

\begin{tabular}{llrrrrr}
\hline Model & & Sum of & & & & \\
& Squares & df & & Mean Square & F & Sig. \\
\hline 1 & Regression & 4.062 & 2 & 2.031 & 4.826 & $.013(\mathrm{a})$ \\
& Residual & 17.674 & 42 & .421 & & \\
& Total & 21.735 & 44 & & & \\
& & &
\end{tabular}

a Predictors: (Constant), IOS, DPR

b Dependentt Variable: DER

Tabel 10 Tabel Uji T Statistik- Coefficients(a)

\begin{tabular}{|c|c|c|c|c|c|c|}
\hline \multirow[b]{2}{*}{ Model } & & \multicolumn{2}{|c|}{ Unstandardized Coefficients } & $\begin{array}{l}\text { Standardized } \\
\text { Coefficients }\end{array}$ & \multirow[b]{2}{*}{$\mathrm{t}$} & \multirow[b]{2}{*}{ Sig. } \\
\hline & & $\bar{B}$ & Std. Error & Beta & & \\
\hline \multirow[t]{3}{*}{1} & (Constant) & .606 & .170 & & 3.565 & .001 \\
\hline & DPR & .000 & .002 & -.009 & -.065 & .948 \\
\hline & IOS & .227 & 075 & .434 & 3.031 & .004 \\
\hline
\end{tabular}

a Dependentt Variable: DER

Dari pengujian Ha2 dapat dibuat model regresi sebegai berikut:

$\mathrm{Y}=0.606+0.000 \mathrm{X} 1+0.277 \mathrm{X} 3+\varepsilon 1$

Keterangan:

$\mathrm{Y}$ : tingkat leverage perusahaan

X1: kebijakan dividen

X3: investment opportunity set (IOS)

Persamaan di atas menunjukkan bahwa tingkat leverage perusahaan akan bernilai konstan sebesar 0.606 jika faktor-faktor lain bernilai nol. Variabel kebijakan dividen bernilai 0.000 menunjukkan bahwa setiap kenaikan dari kebijakan dividen sebesar $1 \%$, maka tingkat leverage perusahaan akan naik sebesar $0.000 \%$, atau dapat dikatakan tidak mempunyai pengaruh. Jika variable moderating IOS bernilai 0.277 menunjukkan bahwa setiap kenaikan dari IOS sebesar Rp 1.000,maka tingkat leverage perusahaan akan naik sebesar Rp 277,-. 


\section{$\mathrm{Ha}_{3}=$ arus kas bebas Berpengaruh terhadap Tngkat Leverage Perusahaan}

\section{Koefisien Determinasi}

Pada Tabel 11 dibawah ini dapat dilihat besarnya nilai koefisien kolerasi (R) sebesar 0.558 atau 55.8\%. Hal ini menunjukkan bahwa pengaruh antara arus kas bebas dengan tingkat leverage perusahaan adalah sedang atau memiliki hubungan. Nilai $\mathrm{R}^{2}$ yang terlihat pada Tabel 11 adalah sebesar 0.311 atau $31.1 \%$ artinya variasi variabel dependent tingkat leverage perusahaan yang bisa dijelaskan oleh independent variable arus kas bebas adalah 31.1\%, sedangkan sisanya $68.9 \%$ dijelaskan variabel lain yang tidak terdapat dalam model regresi tersebut.

Tabel 11 Tabel Uji R dan $R^{2}$ - Model Summary

\begin{tabular}{llllr}
\hline \multicolumn{1}{c}{ Tabel 11} & Tabel Uji R dan R & Model Summary \\
Model & $\mathrm{R}$ & R Square & $\begin{array}{c}\text { Adjusted R } \\
\text { Square }\end{array}$ & $\begin{array}{c}\text { Std. Error of } \\
\text { the Estimate }\end{array}$ \\
\hline 1 & $.558(\mathrm{a})$ & .311 & .295 & .59020 \\
\hline
\end{tabular}

a Predictors: (Constant), AKB

\section{Pengujian Hipotesis}

$\mathrm{Ho}_{3} \quad$ : arus kas bebas tidak berpengaruh terhadap tingkat leverage perusahaan.

$\mathrm{Ha}_{3}$ : arus kas bebas berpengaruh terhadap tingkat leverage perusahaan.

Dari Tabel 12 di bawah ini, nilai sig dari variabel dependent AKB (arus kas bebas) ini 0.000 dan nilai ini lebih kecil dari pada $\alpha=0.05$, artinya $\mathrm{Ho}_{3}$ ditolak dan $\mathrm{Ha}_{3}$ diterima, yaitu arus kas bebas berpengaruh terhadap tingkat leverage perusahaan. Selain itu, dari Gambar 7, nilai $t$ Tabel yang diperoleh 2.0211, sedangkan nilat $t$ hitung yang terdapat pada Tabel 4.8 sebesar -4.404 , dan hal ini menujukkan bahwa nilai $t$ hitungnya lebih kecil dari nilai $t$ Tabel, di mana nilai $t$ hitung ini berada di daerah Ha, maka Ho ditolak dan Ha diterima, serta didukung dengan nilai sig nya.

Dari pengujian Ha3 dapat dibuat model regresi berikut:

$$
\mathrm{Y}=0.780-0.00000006284 \mathrm{X} 3+\varepsilon 1
$$

Keterangan:

$\mathrm{Y}$ : tingkat leverage perusahaan

X3: investment opportunity set (IOS)

Dari model regresi diatas dapat disimpulkan bahwa independent variable arus kas bebas memiliki koefisien regresi sebesar 0.00000006284 yang berarti bila independent variable naik sebesar Rp 100.000.000,- maka dependent variable tingkat leverage perusahaan akan turun sebesar Rp $6.284,-$

Tabel 12 Tabel Uji T Statistik-Coefficients(a)

\begin{tabular}{|c|c|c|c|c|c|c|}
\hline \multirow[b]{2}{*}{ Model } & & \multicolumn{2}{|c|}{ Unstandardized Coefficients } & \multirow{2}{*}{$\begin{array}{c}\begin{array}{c}\text { Standardized } \\
\text { Coefficients }\end{array} \\
\text { Beta } \\
\end{array}$} & \multirow[b]{2}{*}{$\mathrm{t}$} & \multirow[b]{2}{*}{ Sig. } \\
\hline & & $\mathrm{B}$ & Std. Error & & & \\
\hline \multirow[t]{2}{*}{1} & (Constant) & .780 & .106 & & 7.381 & .000 \\
\hline & AKB & $-6.284 \mathrm{E}-07$ & .000 & -.558 & -4.404 & .000 \\
\hline
\end{tabular}

a Dependentt Variable: DER 


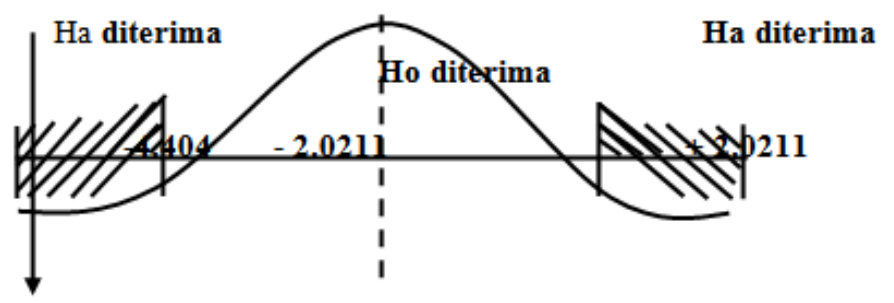

Gambar 7. Kurva Penerimaan atau Penolakan Ha dan Ho.

\section{$\mathrm{Ha}_{4}=$ arus kas bebas dengan investment opportunity set berpengaruh terhadap tingkat leverage perusahaan}

\section{Koefisien Determinasi}

Pada Tabel 13 di bawah ini dapat dilihat besarnya nilai koefisien kolerasi (R) adalah sebesar 0.723 atau $72.3 \%$. Hal ini menunjukan bahwa pengaruh antara arus kas bebas dengan tingkat leverage perusahaan adalah kuat atau memiliki hubungan yang berarti, setelah dimasukannya variable moderating investment opportunity set (IOS). Nilai adjusted $\mathrm{R}^{2}$ yang terlihat pada Tabel 13 adalah sebesar 0.500 atau $50 \%$ yang berarti bahwa variasi dependent variable tingkat leverage perusahaan yang bisa dijelaskan oleh independent variable kebijakan dividen bersama dengan variable moderating investment opportunity set (IOS) adalah sebesar 50\%, sedangkan sisanya sebesar $50 \%$ dijelaskan oleh variable lainnya yang tidak terdapat didalam model regresi tersebut.

\begin{tabular}{ccccc}
\multicolumn{4}{c}{ Tabel 13 TabelUuji R dan $R^{2}$ - Model Summary } \\
\hline Model & $\mathrm{R}$ & R Square & $\begin{array}{c}\text { Adjusted R } \\
\text { Square }\end{array}$ & $\begin{array}{c}\text { Std. Error of the } \\
\text { Estimate }\end{array}$ \\
\hline 1 & $.723(\mathrm{a})$ & .523 & .500 & .49681 \\
\hline
\end{tabular}

a Predictors: (Constant), IOS, AKB

\section{Pengujian Hipotesis}

Ho4 : arus kas bebas dengan investment opportunity set (IOS) tidak berpengaruh terhadap tingkat leverage perusahaan.

Ha4 : arus kas bebas dengan investment opportunity set (IOS) berpengaruh terhadap tingkat leverage perusahaan.

Dari Tabel 14 di bawah ini, nilai sig dari variable dependent DPR (Dividen) dan Variable moderating (IOS) adalah sebesar 0.000 dan nilai ini lebih kecil dari pada $\alpha=0.05$, artinya Ho4 ditolak dan Ha4 diterima, yaitu arus kas bebas dengan investment opportunity set (IOS) berpengaruh terhadap tingkat leverage perusahaan. Selain itu, dari Gambar 4.9 maka nilai $F$ Tabel yang diperoleh adalah sebesar 2.84,. sedangkan nilai $F$ hitung yang terdapat pada Tabel 4.15 adalah sebesar 23.031, dan hal ini menujukkan bahwa nilai $t$ hitungnya lebih besar dari nilai $t$ Tabel, dimana nilai $t$ hitung ini berada didaerah Ho ditolak, maka Ho ditolak dan Ha diterima, dan hal ini didukung pula dengan nilai sig nya.

Tabel 14 Tabel Uji F Statistik-ANOVA(b)

\begin{tabular}{llcrrrr}
\hline & & \multicolumn{2}{c}{ Sum of } & & & \\
Model & & Squares & df & Mean Square & F & Sig. \\
\hline 1 & Regression & 11.369 & 2 & 5.685 & 23.031 & $.000(\mathrm{a})$ \\
& Residual & 10.366 & 42 & .247 & & \\
& Total & 21.735 & 44 & & & \\
\hline
\end{tabular}

a Predictors: (Constant), IOS, AKB

b Dependentt Variable: DER 
Dari pengujian Ha4 dapat dibuat model regresi sebegai berikut:

$$
\mathrm{Y}=0.308-0.00000006544 \mathrm{X} 2+0.241 \mathrm{X} 3+\varepsilon
$$

Keterangan:

$\mathrm{Y}$ : tingkat leverage perusahaan

$\mathrm{X} 2$ : arus kas bebas

X3: investment opportunity set (IOS)

Tingkat leverage perusahaan bernilai konstan sebesar 0.308 jika faktor-faktor lain bernilai nol. Variabel arus kas bebasbernilai 0.00000006544 menunjukan bahwa setiap kenaikan dari arus kas bebassebesar Rp 100.000.000,- maka tingkat leverage perusahaan akan turun sebesar Rp 6.6544. Sedangkan jika variable moderating IOS bernilai 0.241 menunjukan bahwa setiap kenaikan dari IOS sebesar Rp 1.000,- maka tingkat leverage perusahaan akan naik sebesar Rp 241 (Tabel 15).

Tabel 15 Tabel Uji T Statistik-Coefficients(a)

\begin{tabular}{|c|c|c|c|c|c|c|}
\hline \multirow[b]{2}{*}{ Model } & & \multicolumn{2}{|c|}{ Unstandardized Coefficients } & \multirow{2}{*}{$\begin{array}{c}\begin{array}{c}\text { Standardized } \\
\text { Coefficients }\end{array} \\
\text { Beta }\end{array}$} & \multirow[b]{2}{*}{$\mathrm{L}$} & \multirow[b]{2}{*}{ Sig. } \\
\hline & & $\mathrm{B}$ & Std. Error & & & \\
\hline \multirow[t]{3}{*}{1} & (Constant) & .308 & .141 & & .461 & .035 \\
\hline & $\mathrm{AKB}$ & $-6.544 \mathrm{E}-07$ & .000 & -.581 & -5.442 & .000 \\
\hline & IOS & .241 & .056 & .461 & 4.323 & .000 \\
\hline
\end{tabular}

a Dependentt Variable: DER

\section{$\mathrm{Ha}_{5}=$ Kebijakan Dividen dan arus kas bebas berpengaruh terhadap tingkat Leverage perusahaan.}

\section{Koefisien Determinasi}

Pada Tabel 16 di bawah ini dapat dilihat besarnya nilai koefisien kolerasi (R) adalah sebesar 0.581 atau 58.1\%. Hal ini menunjukan bahwa pengaruh antara kebijakan dividen dan arus kas bebas dengan tingkat leverage perusahaan adalah sedang atau memiliki hubungan. Nilai adjusted $\mathrm{R}^{2}$ yang terlihat pada Tabel 16 adalah sebesar 0.306 atau 30.6\% yang berarti bahwa variasi tingkat leverage perusahaan yang bisa dijelaskan oleh kebijakan dividen dan arus kas bebas adalah sebesar 30.6\%, sedangkan sisanya sebesar $69.4 \%$ dijelaskan oleh variable lainnya yang tidak terdapat didalam model regresi tersebut.

Tabel 16 Tabel Uji R dan $R^{2}$-Model Summary

\begin{tabular}{|c|c|c|c|c|}
\hline Model & $\mathrm{R}$ & R Square & $\begin{array}{c}\text { Adjusted R } \\
\text { Square }\end{array}$ & $\begin{array}{l}\text { Std. Error of the } \\
\text { Estimate }\end{array}$ \\
\hline 1 & $.581(\mathrm{a})$ & .337 & .306 & .58561 \\
\hline
\end{tabular}

\section{Pengujian Hipotesis}

$\mathrm{Ho}_{5}$ : Kebijakan Dividend dan arus kas bebas tidak berpengaruh terhadap tingkat Leverage perusahaan.

$\mathrm{Ha}_{5} \quad$ : Kebijakan Dividend dan arus kas bebas berpengaruh terhadap tingkat Leverage perusahaan.

Dari Tabel 17 di bawah ini, nilai sig dari variable dependent DPR (Dividen) dan arus kas bebas sebesar 0.000 dan nilai ini lebih kecil dari pada $\alpha=0.05$, artinya Ho5 ditolak dan Ha5 diterima, yaitu kebijakan dividen dan arus kas bebas berpengaruh terhadap tingkat leverage perusahaan. Selain itu, nilai $F$ Tabel yang diperoleh adalah sebesar 2.84. Sedangkan nilai $F$ hitung yang terdapat pada 
Tabel 17 adalah 10.690, dan hal ini menujukkan bahwa nilai $t$ hitungnya lebih besar dari nilai $t$ Tabel, dimana nilai $t$ hitung ini berada didaerah Ho ditolak, maka Ho ditolak dan Ha diterima, dan hal ini didukung pula dengan nilai sig nya.

Tabel 17 Tabel Uji F Statistik-ANOVA(b)

\begin{tabular}{llrrrrr}
\hline Model & & Sum of & & & & \\
& & Squares & df & Mean Square & \multicolumn{1}{c}{ F } & Sig. \\
\hline 1 & Regression & 7.332 & 2 & 3.666 & 10.690 & .000 (a) \\
& Residual & 14.403 & 42 & .343 & & \\
& Total & 21.735 & 44 & & & \\
\hline
\end{tabular}

a Predictors: (Constant), AKB, DPR

b Dependentt Variable: DER

Dari pengujian Ha5 dapat dibuat model regresi sebagai berikut:

$$
\mathrm{Y}=0.719+0.002 \mathrm{X} 1-0.00000006504 \mathrm{X} 2+\varepsilon 1
$$

Keterangan:

$\mathrm{Y}$ : Tingkat leverage perusahaan

X1: Kebijakan Dividen

X2: arus kas bebas

Persamaan di atas menunjukkan bahwa tingkat leverage perusahaan akan bernilai konstan sebesar 0.719 (Tabel 18) jika faktor-faktor lain bernilai nol. Variabel kebijakan dividen 0.00000006544 menunjukan bahwa setiap kenaikan dari kebijakan dividen sebesar 1\%, maka tingkat leverage perusahaan akan naik sebesar $0.719 \%$. Jika variable arus kas bebas bernilai 0.00000006504 menunjukan bahwa setiap kenaikan dari arus kas bebas sebesar Rp 100.000.000,- maka tingkat leverage perusahaan akan turun sebesar Rp 6.504,-.

Tabel 18 Tabel Uji T Statistik-Coefficients(a)

\begin{tabular}{|c|c|c|c|c|c|c|}
\hline \multirow[b]{2}{*}{ Model } & & \multicolumn{2}{|c|}{$\begin{array}{l}\text { Unstandardized } \\
\text { Coefficients }\end{array}$} & $\begin{array}{c}\text { Standardized } \\
\text { Coefficients } \\
\end{array}$ & \multirow[b]{2}{*}{$\mathrm{t}$} & \multirow[b]{2}{*}{ Sig. } \\
\hline & & $\mathrm{B}$ & Std. Error & Beta & & \\
\hline \multirow[t]{3}{*}{1} & (Constant) & .719 & .115 & & 6.239 & .000 \\
\hline & DPR & .002 & .002 & .164 & 1.295 & .202 \\
\hline & AKB & $-6.504 \mathrm{E}-07$ & .000 & -.577 & -4.561 & .000 \\
\hline
\end{tabular}

a Dependentt Variable: DER

\section{$\mathrm{Ha}_{6}=$ Kebijakan Dividen, Arus kas bebas, Investment Opportunity Set (IOS) Berpengaruh terhadap Tingkat Leverage Perusahaan.}

\section{Koefisien Determinasi}

Pada Tabel 19 ini dapat dilihat besarnya nilai koefisien kolerasi (R) adalah sebesar 0.725 atau 72.5\%. Hal ini menunjukan bahwa pengaruh antara kebijakan dividen, arus kas bebas, investment opportunity set (IOS) dengan tingkat leverage perusahaan adalah kuat atau memiliki hubungan yang berarti. Nilai adjusted $\mathrm{R}^{2}$ yang terlihat pada Tabel 19 adalah sebesar 0.491 atau $49.1 \%$ yang berarti bahwa variasi dependent variable tingkat leverage perusahaan yang bisa dijelaskan oleh independent variable kebijakan dividen dan arus kas bebas bersama dengan variable moderating IOS adalah sebesar $49.1 \%$, sedangkan sisanya sebesar 50.9\% dijelaskan oleh variable lainnya yang tidak terdapat di dalam model regresi tersebut. 
Tabel 19 Tabel Uji R dan $R^{2}$ - Model Summary

\begin{tabular}{ccccc}
\hline Model & $\mathrm{R}$ & R Square & $\begin{array}{c}\text { Adjusted R } \\
\text { Square }\end{array}$ & $\begin{array}{c}\text { Std. Error of the } \\
\text { Estimate }\end{array}$ \\
\hline 1 & .725 (a) & .526 & .491 & .50122 \\
\hline
\end{tabular}

a Predictors: (Constant), IOS, AKB, DPR

\section{Pengujian Hipotesis}

$\mathrm{Ho}_{6} \quad$ : kebijakan dividend, arus kas bebas, investment opportunity set (IOS) tidak berpengaruh terhadap tingkat leverage perusahaan.

$\mathrm{Ha}_{6} \quad$ : kebijakan dividend, arus kas bebas, investment opportunity set (IOS) berpengaruh terhadap tingkat leverage perusahaan.

Dari Tabel 4.20 nilai sig dari variable dependent DPR (Dividen) dan arus kas bebas (AKB), serta IOS adalah sebesar 0.000 dan nilai ini lebih kecil dari pada $\alpha=0.05$, artinya Ho5 ditolak dan Ha5 diterima, yaitu kebijakan dividen, arus kas bebas, investment opportunity set berpengaruh terhadap tingkat leverage perusahaan. Selain itu, dari Tabel 20 nilai $F$ Tabel yang diperoleh adalah sebesar 2.84,. sedangkan nilai $F$ hitung yang terdapat pada Tabel 20 adalah sebesar 15.173, dan hal ini menujukkan bahwa nilai $t$ hitungnya lebih besar dari nilai $t$ Tabel, dimana nilai $t$ hitung ini berada didaerah Ho ditolak, maka Ho ditolak dan Ha diterima, dan hal ini didukung pula dengan nilai sig nya.

Tabel 20 Tabel Uji F Statistik-ANOVA(b)

\begin{tabular}{|c|c|c|c|c|c|c|}
\hline Model & & $\begin{array}{c}\text { Sum of } \\
\text { Squares }\end{array}$ & Df & Mean Square & $\mathrm{F}$ & Sig. \\
\hline \multirow[t]{3}{*}{1} & Regression & 11.435 & 3 & 3.812 & 15.173 & $.000(a)$ \\
\hline & Residual & 10.300 & 41 & .251 & & \\
\hline & Total & 21.735 & 44 & & & \\
\hline
\end{tabular}

a Predictors: (Constant), IOS, AKB, DPR

b Dependentt Variable: DER

Dari pengujian Ha6 dapat dibuat model regresi sebagai berikut:

$$
\mathrm{Y}=0.300+0.001 \mathrm{X} 1-0.00000006613 \mathrm{X} 2+0.234 \mathrm{X} 3+\varepsilon 1
$$

Keterangan:

$\mathrm{Y}$ : tingkat leverage perusahaan

X1: kebijakan dividen

X2: arus kas bebas

X3: investment opportunity set

Persamaan di atas menunjukkan bahwa tingkat leverage perusahaan akan bernilai konstan sebesar 0.300 jika faktor-faktor lain bernilai nol. Variabel kebijakan dividen 0.001 menunjukan bahwa setiap kenaikan dari kebijakan dividen sebesar 1\%, maka tingkat leverage perusahaan akan naik sebesar $0.001 \%$. Sedangkan jika variable arus kas bebas bernilai 0.00000006613 menunjukan bahwa setiap kenaikan dari arus kas bebas sebesar Rp 100.000.000,- maka tingkat leverage perusahaan akan turun sebesar Rp 6.613,-. Sedangkan jika variable moderating IOS bernilai 0.234 menunjukkan bahwa setiap kenaikan dari IOS sebesar Rp 1.000,- maka tingkat leverage perusahaan akan naik sebesar Rp 234,- (Tabel 21). 
Tabel 21 Tabel Uji T Statistik-Coefficients(a)

\begin{tabular}{|c|c|c|c|c|c|c|}
\hline \multirow[b]{2}{*}{ Model } & & \multicolumn{2}{|c|}{ Unstandardized Coefficients } & $\begin{array}{l}\text { Standardized } \\
\text { Coefficients }\end{array}$ & \multirow[b]{2}{*}{$\mathrm{t}$} & \multirow[b]{2}{*}{ Sig. } \\
\hline & & $\mathrm{B}$ & Std. Error & Beta & & \\
\hline \multirow[t]{4}{*}{1} & (Constant) & .300 & .143 & & 2.097 & .042 \\
\hline & DPR & .001 & .002 & .057 & .513 & .610 \\
\hline & AKB & $-6.613 \mathrm{E}-07$ & .000 & -.587 & -5.418 & .000 \\
\hline & IOS & .234 & .058 & .448 & 4.041 & .000 \\
\hline
\end{tabular}

a Dependentt Variable: DER

\section{PENUTUP}

\section{Simpulan}

Penelitian ini bertujuan untuk menguji atau melihat apakah ada pengaruh investment opportunity set (IOS) terhadap hubungan antara kebijakan dividen dan arus kas bebas terhadap tingkat leverage perusahaan. Dengan menggunakan 42 sampel perusahaan makanan dan minuman yang terdaftar di BEI untuk periode 2003-2007, penelitian ini mendapatkan kesimpulan sebagai berikut: (1) Hasil moderated regression analysis menyimpulkan bahwa kebijakan dividen tidak mempengaruhi leverage perusahaan. Hasil penelitian ini menunjukkan hal yang berbeda dengan hasil penelitian sebelumnya yang dilakukan oleh Yusef Widya Karsana dan Supriyadi (2005); (2) Hasil moderated regression analysis menyimpulkan bahwa kebijakan dividen dengan investment opportunity set berpengaruh terhadap tingkat leverage perusahaan. Hasil ini mendukung hasil penelitian sebelumnya yang dilakukan Yusef Widya Karsana dan Supriyadi (2005); (3) Hasil moderated regression analysis menyimpulkan bahwa arus kas bebas berpengaruh terhadap tingkat leverage perusahaan. Dari hasil penelitian ini maka hasilnya tidak sesuai dengan hasil penelitian sebelumnya yang dilakukan Yusef Widya Karsana dan Supriyadi (2005); (4) Hasil moderated regression analysis menyimpulkan bahwa arus kas bebas dengan investment opportunity set (IOS) berpengaruh terhadap tingkat leverage perusahaan. Hasil penelitian ini sesuai dengan hasil penelitian sebelumnya yang dilakukan Yusef Widya Karsana dan Supriyadi (2005); (5) Hasil moderated regression analysis menyimpulkan bahwa kebijakan dividen dan arus kas bebas berpengaruh terhadap tingkat leverage perusahaan. Sedangkan hasil penemuan ini berbeda dengan hasil penelitian sebelumnya yang dilakukan oleh Yusef Widya Karsana dan Supriyadi (2005); (6) Hasil moderated regression analysis menyimpulkan bahwa kebijakan dividen, arus kas bebas, investment opportunity set berpengaruh terhadap tingkat leverage perusahaan. Hasil penelitian ini mendukung hasil penelitian Yusef Widya Karsana dan Supriyadi (2005).

\section{Keterbatasan}

Penelitian ini masih memiliki beberapa keterbatasan dan karenanya masih perlu dikembangkan lagi pada penelitian berikutnya. Adapun beberapa keterbatasannya seperti: (1) Penelitian ini hanya menguji investment opportunity set (IOS) sebagai variable moderating pada hubungan antara kebijakan dividen dengan leverage perusahaan; (2) Penelitian ini hanya menggunakkan salah satu proksi investment opportunity set (IOS) yang berbasis harga yaitu dengan menggunakkan ratio market to book value equity; (3) Sample perusahaan dalam penelitian ini hanya mencakup perusahaan makanan dan minuman yang terdaftar di BEI pada periode 2003-2007; (4) Penelitian ini tidak memasukkan beberapa variable lain yang mungkin relevan seperti antara lain struktur kepemilikan perusahaan, size, dan seterusnya. 


\section{Rekomendasi}

Beberapa rekomendasi yang dapat diutarakan, antara lain: (1) Bagi para investor penelitian ini dapat digunakan jika investor ingin melakukan suatu investasi dapat melihat kebijakan dividen dan arus kas bebas dengan leverage perusahaan yang dengan memasukkan investment opportunity set ini sebagai variable moderatingnya; (2) Untuk penelitian selanjutnya sebaiknya menambahkan sample penelitian yang lebih banyak, tidak hanya terfokus pada perusahaan makanan dan minuman saja. Tetapi bisa perusahaan manufaktur lainnya, selain itu periode penelitian yang dilakukan pun bisa diperpanjang; (3) Selain itu, dapat menambahkan variable moderating yang ada, tidak hanya menggunakkan investment opportunity set (IOS), tetapi dapat menggunakan profitabilitas, struktur kepemilikan, dan lain-lain. Penambahan variable moderating dapat membuat atau memberikan pemahan yang semakin lengkap tentang faktor-faktor yang mempengaruhi hubungan antara kebijakan dividen dan arus kas bebas dengan tingkat leverage perusahaan terutama yang berkaitan dengan teori keagenan; (4) Proksi investment opportunity set (IOS) yang digunakan tidak hanya berbasis harga saja, tetapi juga dapat menggunakan proksi berbasis investasi dan varian untuk melihat tingkat konsistensi atau validitas dari hasil penelitian; (5) Lebih baik memasukkan variabel struktur kepemilikan karena akan memberikan gambaran yang lebih jelas lagi tentang hubungan arus kas bebas dengan kepemilikan karena agency cost berhubungan dengan struktur kepemilikan (Agrawal dan Jayaraman, 1994).

\section{DAFTAR PUSTAKA}

Adedeji, A. (1998). Does the packing order hypothesis explain the dividend payout ratIOS of firm in the UK. Journal of Business Finance \& Accounting, 25, 1127-1155.

Allen, D.E. (1993). The packing order hypothesis Australian evidence. Applied Financial Economies, $3,101-112$.

Bodie, Kane, Marcus. (2008). Investment. Singapore: Mc Graw-Hill International.

Brigham, E. F. (2005). Financial Management: Theory and Practice, international edition. Boston: South Western College Publishing.

Ghozali, Imam, (2006). Aplikasi Analisis Multivariate dengan Program SPSS, edisi IV. Semarang: Badan Penerbit Universitas Diponegoro.

Hartono, J. (1999). An Agency Cost Explanation for Dividend Payments. Karya tulis tidak diterbitkan. Yogyakarta: Universitas Gadjah Mada.

Jensen. M. C. (1995). Agency Cost of Free Cash Flow, Cooperate Ownership: Causes and Consequences. Journal of Political Economy, 93.

Myres. S. C. (1997). Determines of Cooperate Borrowing. Journal of Financing Economics, 5, 147175. 